\title{
OS CANEIROS DE PORTOMARÍN: ACHEGA A UN PECULIAR E DESAPARECIDO SISTEMA DE PESCA DA ANGUÍA NO RÍO MIÑO
}

\author{
Por \\ XOSÉ LOIS LADRA FERNÁNDEZ ${ }^{1}$
}
Ás xentes de Portomarín, que aínda gardan con orgullo na memoria os traballos e os días dos seus devanceiros.

\section{O VOCABLO CANEIRO. ACHEGA ÁS SÚAS ORIXES E SIGNIFICADOS}

Arredor da idea do caneiro artéllase a historia que de seguido vou contar; é por iso que cómpre primeiro ter mínimamente claro a que nos estamos a referir e cal é a significación etimolóxica deste vocablo.

O termo galego-portugués caneiro vén significar aproximadamente, nunha das súas múltiples acepcións actuais «pesqueira, canle composta ordinariamente de dúas estacadas ou muros, chamados guiares, que forman no río unha represa no boquete da cal se colocan as redes para pescar anguías, reos, sábalos...» (RODRÍGUEZ GONZÁLEZ, E., 1958, Vol. I: 465).

Caneiro deriva de cana, é dicir, do vocablo latino canna, que significa literalmente «cana» ou «xunco». Esta etimoloxía xa nos está a falar do material primixenio co cal se fabricaron estas construccións. Por outra

\footnotetext{
${ }^{1}$ A totalidade dos debuxos que acompañan ao presente artigo, son da autoría de D. Cristovo Fernández Casás, a quen quero agradecer públicamente unha vez máis o seu apoio e constante colaboración.
}

"CUADERNOS DE ESTUDIOS GALLEGOS", Tomo XLV, Fascículo 110, Santiago 1998. 
banda, tampouco convén esquecer a relación, máis ca evidente, que existe entre as palabras canna e cannalis, querendo significar esta última «canle» ou «canal».

Caneiro tamén pode significar seguindo este primeiro étimo «agrupación de canas» co cal, como topónimo, pode indicar dúas realidades ben diferentes. Así, ou ben indica un fitónimo de lugar onde podemos atopar xuncos -é dicir, o que noutras palabras chamaríamos canaveiral, canaval, canavial, canizo, canizal, canizada, canedo, caneda, carrizal ou carrizo- ou ben refírese ao lugar onde están ou estiveron presentes este tipo de construccións. Sinónimos galego-portugueses desta segunda acepción de caneiro son canizo/caniço e canal.

Esta mesma palabra existe en bable como caneiru, en castellano como cañal, cañal, cañar ou cañaliega e en catalá como canyar ou canyeta. En todas estas línguas pódese procurar como topónimo equivalente, só que o problema -igualmente ao que acontece co galego- radica en poder discernir en cada caso a cal das dúas acepcións etimolóxicas debe a súa orixe como vocablo o nome de lugar.

Resulta interesante reparar na definición exacta que algúns diccionarios enciclopédicos ofertan sobre o correspondente vocablo castellano cañal: «Arte fijo principalmente empleado para la pesca fluvial, pero que también se usa para la marítima en las playas donde la marea es bastante sensible. Está formado este arte por un conjunto de muchas cañas de altura proporcionada a la de la marea, colocadas derechas y unidas en línea recta formando paredes, que de dos en dos se unen en ángulo agudo, en el que se coloca una nasa o cestón» (ENCICLOPEDIA, 1958, Vol. XI: 308).

A partires de aquí non resulta demasiado complexo deducir o uso tanto fluvial coma marítimo desta caste de construccións artificiais. Cómpre facer xa dende agora unha aclaración: aínda que os caneiros foron empregados para a captura de diferentes especies piscícolas marítimas ou fluviais, procurarei centrarme preferentemente nos casos en que éstes se artellan para a pesca fluvial das anguías, que sempre foi maioritariamente desenrolada e de forma senlleira neste tipo de construccións.

Un dato interesante a ter en conta é o feito de que o topónimo caneiro, expresado nas diferentes línguas peninsulares, pode ser fácilmente detectado en diversas comunidades autónomas. Así, por poñer tan só algúns exemplos, en Galicia constatamos varios microtopónimos tipo Os caneiros, sempre vencellados a ámetos ecolóxicos fluviais, como pode ser o caso 
do localizado no Concello de Betanzos (A Coruña) ou o do Concello de Portomarín (Lugo); en Asturies, desemboca na vila de Tapia de Casariego o chamado Río Anguileira, e perto de Lluarca aparece a aldea de Caneiru, bárbaramente deturpada na súa toponimia oficial co vocablo castelanizador Canero, cando a súa equivalencia correcta nesta língua sería Cañal ou Canal, como xa vimos antes. Tampouco faltan exemplos de nomes de lugar chamados canyar en Catalunya, nin canais en terras portuguesas.

Todo isto vén confirmar o feito de que ao longo da historia as xentes souberon conservar os nomes daqueles lugares nos que, ou ben constataron unha elevada presencia de canas como plantas propias de certos ámetos fluviais, ou ben decidiron chamar desta maneira a aquelas poboacións nas que o sistema de pesca antes descrito foi algunha vez empregado, deixando así a súa impronta toponímica.

A este respecto, diversos investigadores teñen insistido nesta dicotomía, facéndonos saber que «A un conxunto de canas refírese o fitónimo Canaval. Abundanciais en -eira, -eiro do mesmo vexetal parecen Caneiro, Caneiros e Os Caneiros, que tamén poden referirse a un tipo de pesqueira fluvial chamada caneiro, en alusión á canle onde se colocan as redes.» (CABEZA, 1992: 26).

\section{OS CANEIROS DO MIÑO: UN FEITO ETNOGRÁFICO ESQUENCIDO}

Ao longo do curso do Pai Miño e de moitos dos seus afluentes tributarios podemos constatar a presencia destas peculiares construccións arquitectónicas implementads polo home para optimizar a explotación dos recursos piscícolas que oferta o río. De entre éstes, unha das especies máis valoradas pola nosa gastronomía xunto coa lamprea, foi sempre a anguía.

Cómpre dicir que a anguía e a súa cría, a angula ou meixón, foi pescada en moitas das nosas vilas e aldeas ao longo e ancho de Galicia, a primeira nos ríos e a segunda na beiramar, e foi capturada con moitos e moi diversos aparellos. Non é este o lugar axeitado para estudiar polo miúdo todos e cada un deles, polo cal voume centrar na vila de Portomarín e nos caneiros alí artellados sobre o Miño, que fornecen a maioría dos datos apresentados neste traballo. 
Nas miñas viaxes tiven a oportunidade de visitar as pesqueiras do Baixo Miño e as do Ulla, así coma os caneiros da Terra Chá, os das inmediacións da capital lucense e os da bisbarra de Portomarín-Paradela. Foi nesta, nos ríos Miño, Loio e Ferreira onde reparei con maior intensidade na pescuda de informadores que pudesen contribuír, cos seus coñecimentos ou coas súas propias experiencias, a comprender un xeito tan peculiar de explotar os recursos piscícolas existentes nos ríos que percorren as súas terras.

\section{A PESCA DA ANGUía NA ECONOMÍA TRADICIONAL PORTOMARINENSE}

A antiga vila medieval -hoxe desgraciadamente asulagada polas augas miñotas a causa da construción do encoro de Belesar- foi declarada Conxunto Histórico-Artístico por Decreto de oito de febreiro de 1946. Ésta ocupaba ámbalas dúas marxes do Miño, coa freguesía de S. Pedro a unha beira e a de S. Xoán ou S. Nicolás na outra. Unha vella ponte facilitaba as comunicacións transfluviais entre as dúas ribeiras. Neste treito do Miño sempre se deron ben troitas, anguías, lampreas, salmonetes e reos, aínda que moitas delas desapareceron logo da construcción do encoro de Os Peares.

A economía portomarinense sempre tivo ao longo da súa historia e aínda hoxe segue a ter un carácter eminentemente agropecuario e de autoconsumó. Non cabe dúbida que a agricultura e a gandería empregan á inmensa maioría da súa poboación, mais tamén hai que ter en consideración o papel da pesca, especialmente en tempos anteriores á posta en funcionamento do Encoro de Belesar, en febreiro do ano 1.963. De todos os xeitos, falar da pesca fluvial tradicional en Portomarín é falar da pesca da anguía, pois éste era o peixe máis apreciado e o que maior volume de capturas fornecía aos pescantíns.

Son abondosas as referencias históricas á proverbial riqueza anguieira desta vila. Así, xa no século XVI, o Licenciado Molina ao falar destas terras dicía que «el río cría allí y ay tanta multitud de anguilas: que no podiéndose gastar se salan y llevan por el reyno» (MOLINA, 1550: 36).

Un par de centurias máis tarde, xa no s. XVIII, será o insigne polígrafo Cornide e Saavedra quen ratifique as verbas denantes mentadas, ao salientar o feito de que o Miño «pasa a enriquecer con su abundancia de 
anguilas la villa de Portomarín, surtiendo [ésta] con ellas el reino [de Galicia] y parte de Castilla» (PEDRET, 1950:135).

Por outra banda, a comezos do século XIX era José Lucas Labrada quen ao falar do val de Portomarín afirmaba que éste producía «vino, centeno y castañas, y el río excelentes anguilas» (LABRADA, 1804: 148). E finalmente, referíndose tamén ao Vello Portomarín dos anos cincuenta deste século, o erudito local Gonzalo Paz López aseveraba que «La pesca constituye un capítulo importante en la vida económica de Portomarín, siendo тиy pocos los habitantes que no se dedican a esta actividad.» (PAZ, 1961:118-19).

Convén salientar que a pesca da anguía non só se limitaba económicamente á súa extracción para o autoconsumo, senón que o elevado volume de capturas favoreceu o desenrolo de industrias locais especializadas en arranxar os diferentes aparellos de pesca, salgar o peixe e comercializalo cara ao exterior. Antes da inauguración do encoro de Belesar eran moitas as familias que se adicaban á pesca da anguía, e incluso algunhas vivían cáseque exclusivamente dela.

As informacións que agora imos detallar corresponden aos anos anteriores á construcción do encoro, nos cales a pesca da anguía era unha actividade normal e de longa tradición. Todas elas foron extraídas a partires dos relatos de informantes que participaron directa ou indirectamente nestes labores.

\section{OS CANEIROS: UNHA ARQUITECTURA POPULAR ESPE- CIALIZADA}

A pesca da anguía efectuábase ao longo de diversas épocas do ano, dependendo das diferentes artes ou modalidades piscícolas empregadas. Entre éstas, poderíamos salientar frisgas, galleiros, cordas, nasos, chumbeiras ou esparaveis, pardellos, canas, garfos, secas, caneiras e caneiros.

Respecto aos caneiros e ás caneiras, dada a súa complexidade e especificidade, procuraremos explicalos con certa profundidade, ao seren obxecto principal deste traballo. A diferencia entrámbolos dous tipos constructivos é moi sinxela: as caneiras teñen unha soa boca, namentres os caneiros apresentan sempre dúas ou máis.

"CUADERNOS DE ESTUDIOS GALLEGOS", Tomo XLV, Fascículo 110, Santiago 1998. 
Os caneiros observables na actualidade dende a Ponte Nova de Portomarín pertencen alomenos a tres concellos diferentes: ao propio Portomarín, ao de O Páramo e ao de Paradela. Tamén existen mostras destas arquitecturas noutros concellos lucenses, mais fican fóra do ámeto deste traballo, aínda que non por iso deixen de merecer o interese de futuras pesquisas.

Describiríamos os caneiros (ver Fig. 1) como aquelas construccións populares de ubicación preferentemente fluvial utilizadas principalmente para a captura da anguía cando ésta desce polo curso do río aproveitando as riadas causadas polas fortes choivas do outono. Están formados por dous muros alongados feitos con chantos de xisto, lousa ou pólas, dispostos a xeito de funil e chamados espigas, espigóns ou guiares, que converxen sen chegar a se pechar, deixando unha abertura ou canle na cal se localiza a pía, que é unha ínsua de feitura triangular. Entre a pía e os guiares se deixan dúas bocas, canles nas que se arman as redes para pescar. Ás veces, a propia pía segméntase en treitos para acoller máis bocas.

As espigas aséntanse directamente sobre o leito fluvial, dispoñéndose de xeito diagonal e converxente a favor da corrente do río. Levan uns calzos na súa vertente exterior afortalados por un entullo de coios. As espigas están formadas, como xa dixemos, por chantos trabados solapadamente de cara a favorecer unha menor resistencia ás augas para implementar así unha maior hidrodinamicidade á construcción.

Sobor da pía constrúese unha caseta permanente de xisto no caso das mellor dotadas, ou unha pallaza temporal a base de xestas e palla nas de menor complexidade. Nesta caseta ou pallaza cobíxanse os pescantíns durante as noites de faena.

Un caneiro armado apresentaríase da seguinte maneira (ver Fig. 2): en cada boca ou canle disponse baixo as augas a cadea, tronco fixo, xeralmente de piñeiro ou de ameneiro verde debido á sua maior resistencia á humidade, a cal vai trabada entre a base da pía e a do carrual ou extremo proximal da espiga. Xunto ca cadea colócase o tesón ou vara estreita e alongada de castiñeiro ou ameneiro, asimesmo colocada entre a trabe de madeira ubicada na parte alta da pía e o carrual. Ámbalas dúas pezas, a cadea e o tesón, exercen de tope ao arco da rede para evitaren que ésta se desprace e sexa arrastrada pola corrente. Como complemento de seguranza, a rede vai amarrada á trabe cunha corda da cal turran os pescantíns cando van desarmala, logo de retiraren o tesón.

"CUADERNOS DE ESTUdIOS GALLEGOS", Tomo XLV, Fascículo 110, Santiago 1998. 

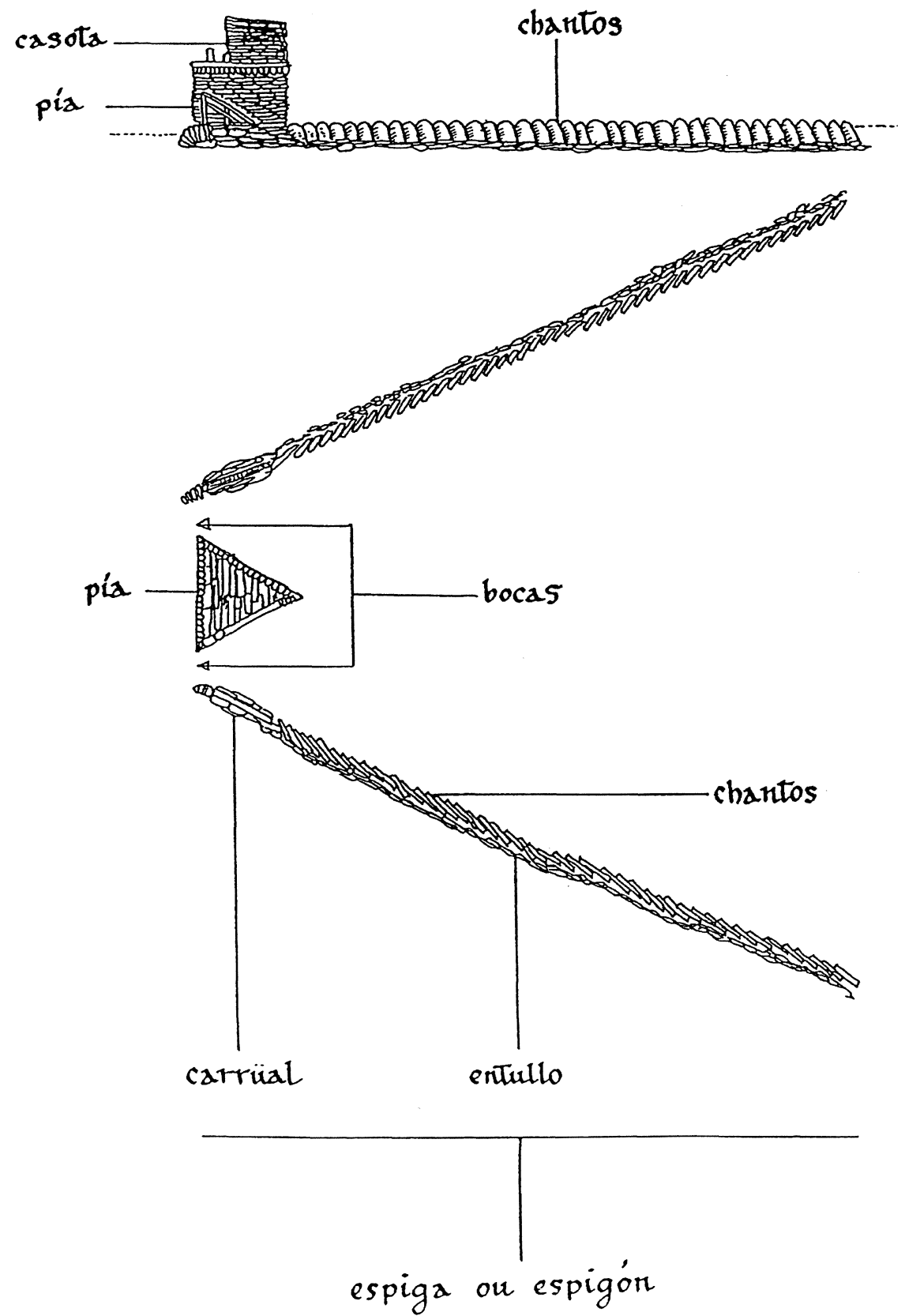

Fig. 1.- Planta e alzado dun caneiro. 


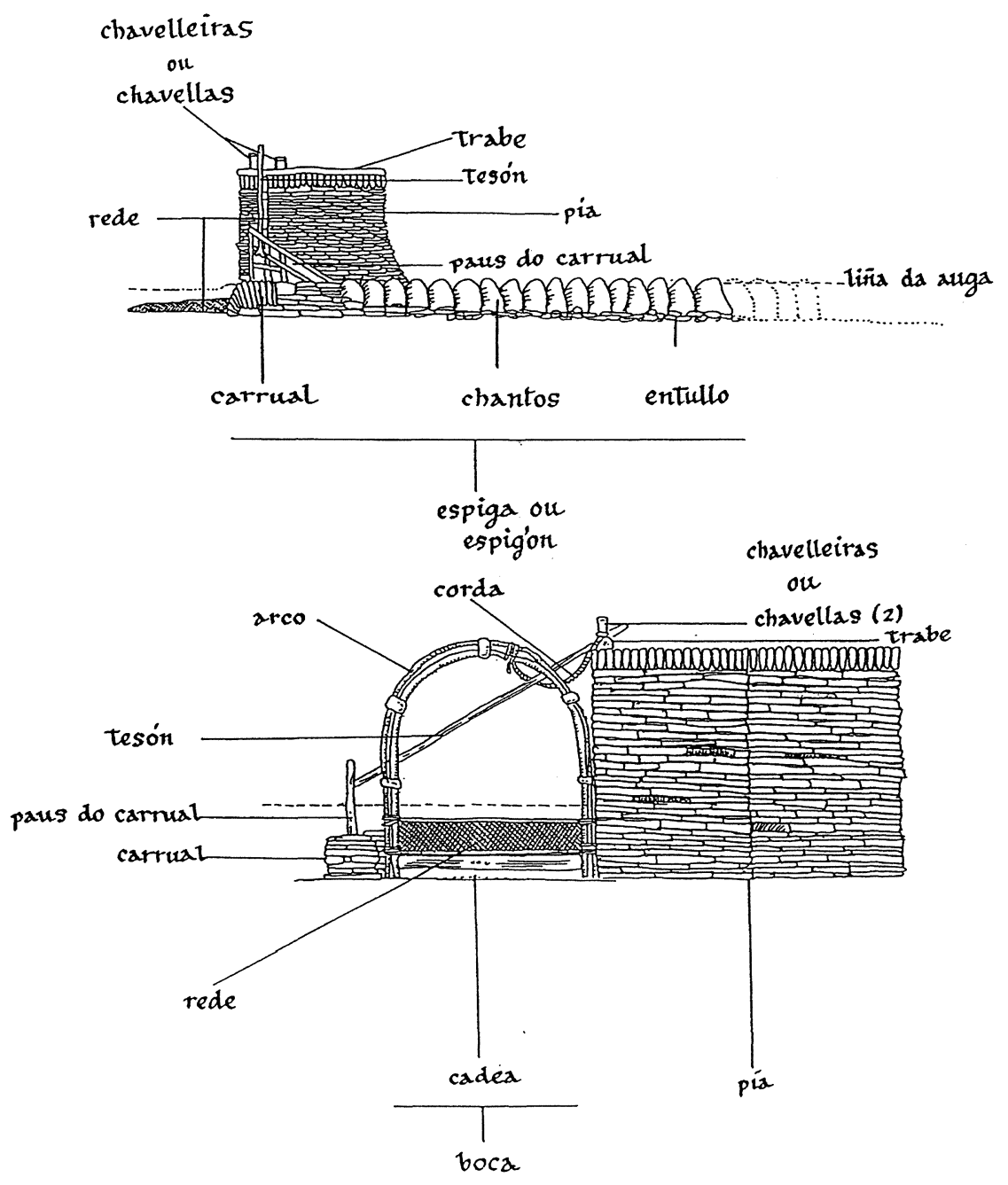

Fig. 2.- As partes do caneiro (perfil e frente) 


\section{A CONSTRUCCIÓN DUN CANEIRO: FASES, TÉCNICAS E MATERIAIS}

Segundo as informacións facilitadas por diversos pescantíns que participaron nos labores de construcción dos caneiros, éstes levábanse a cabo no verán, época do ano na que o río leva pouco caudal, ofrecendo menor resistencia á alteración da fisonomía do seu leito.

Calquer lugar que non entorpeza directamente a pesca dos caneiros xa existentes pode ser seleccionado para erguer un novo. A ubicación máis axeitada dun caneiro será aquela parte do cauce na que o río en época de crecidas amose un maior e mellor número de cachóns ou turbulencias; isto débese ao feito de que as anguías, o mesmo que outras especies piscícolas, amosan unha clara preferencia polas augas rápidas e ben osixenadas.

Nun primeiro momento constrúese a pía (ver Fig. 3.1), para o cal inicialmente prepárase a súa base co fin de asentar con xeito os paramentos exteriores de mampostería de xisto. Neste proceso os esquinais reciben un tratamento máis coidadoso e homoxéneo, pois eles serán os que deban soportar as maiores presións da corrente do río. A cima dos muros remátase con pedras dispostas a xeito de chapacuña, é dicir, chantadas diagonalmente unha tras doutra no sentido da corrente para ofrecer unha menor resistencia á capacidade erosiva das augas.

Asimesmo, no feitío a xeito de triángulo equilátero que amosa a pía, ésta sempre apresentará a sua proa afiada como primeiro obstáculo a superar pola corrente, á cal corta coma se dun coitelo afiado se tratase, forzando a dividir o ímpetu da mesma en dous vectores diverxentes, cada un dos cales avanzará polos laterais da pía, esquivando a base recta desta ínsua. Con todo isto acádase unha mellor hidrodinamicidade da obra para así garantir unha maior perdurabilidade á mesma.

Unha intención clara dos constructores de caneiros é garantir, na medida das súas posibilidades, a máis longa vida posible ás súas construccións, pois éstas deberán transmitirse como herdanza de xeración en xeración, para manterse en uso ao longo de varios decenios ou mesmo séculos enteiros. Fique pois fóra de toda dúbida a vocación de durabilidade destas construccións.

Nunha segunda fase (ver Fig. 3.2), o interior da pía rechéase cun entullo de diversas pedras tales coma xistos, seixos ou cantos rolados, procu-

"CUADERNOS DE ESTUDIOS GALLEGOS", Tomo XLV, Fascículo 110, Santiago 1998. 


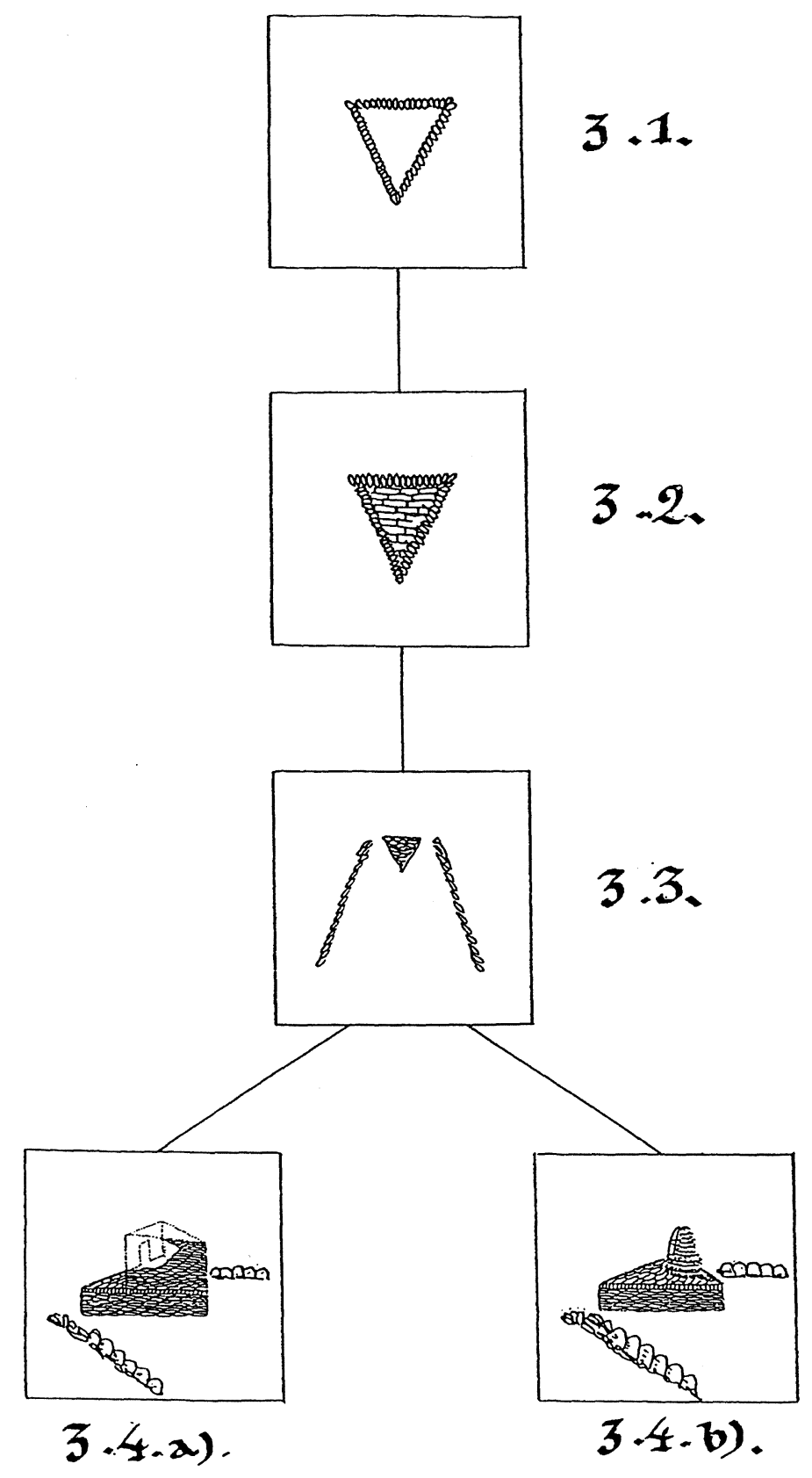

Fig. 3.- Fases da construcción dun caneiro. 
rando homoxeneizar a fábrica e dotala da solidez suficiente para garantir a súa perdurabilidade. Unha vez rematada a elaboración da pía procédese ao erguemento das espigas ou guiares (ver Fig. 3.3), nas cales gardaranse certos principios edilicios básicos. Así, éstas deben estar perfectamente asentadas no leito do río, para o cal habilítanse en primeira instancia uns calzos sobor dos cales inzarán os chantos, que irán dispostos de maneira solapada e concatenada.

Con posterioridade ao seu erguemento e calzamento, os espigóns recibirán o aporte dun recheo exterior a maneira de entullo heteroxéneo que garanta a súa estabilidade. A peculiar disposición das lousas favorece unha menor resistencia á corrente e unha mellor canalización das augas cara ás bocas. Cómpre dicir aquí que, aínda que a grande maioría das espigas foran elaboradas con lousas ou xistos, tamén se facían con troncos e pólas ou incluso con ámbolos dous tipos de materiais cando non se dispoñía de pedra dabondo. Nas pías dotadas de caseta, ésta constrúese a seguir do proceso anteriormente descrito.

Logo do axeitamento do carrual ou parte proximal da espiga, colócase a cadea, a cal irá trabada entre as bases de aquél e da pía. Finalmente arránxase unha trabe, normalmente de madeira de castiñeiro ou ameneiro, que irá instalada nun canto da cima da pía, perto da súa base maior.

Agora que a estructura básica do caneiro xa está rematada, os constructores atópanse con dúas opcións á hora de erguer unha casoupa que dé acobillo aos pescantíns durante o desenvolvemento do seu traballo: por una banda poden facer unha caseta de pedra e pola outra unha pallaza de colmo. Todo depende de dous factores: a disponibilidade de materiais e a riqueza do seu promotor. Evidentemente, a relación existente entre estes factores determinará a opción edilicia a tomar.

Se se pretende facer unha casoupa estable e duradeira, ésta farase de pedra. Para elo precisarase dunha maior cantidade de materiais, incrementando o custo da obra, pero a ventaxa a longo prazo resulta convincente: poderase dispoñer dunha caseta estable e perdurable no tempo. Ésta sóese facer con paramento de xisto e cuberta de lousa, amosando unha porta de madeira dunha soa folla e feitío rectangular clásico na parte traseira da mesma (ver Fig. 3.4a). En Portomarín non se documenta o recebado exterior dos paramentos, mais en certos caneiros das inmediacións da capital lucense aínda hoxe podemos observar esta técni- 
ca, claramente destinada a isolar o interior da construcción de humidades e a darlle maior vistosidade exterior á mesma.

Se esta inversión de tempo, traballo e materiais non resultase factible para o promotor, entón deixaríase o caneiro tal cal, agardando á época de traballo para construir unha pallaza de carácter temporal (ver Fig. 3.4b). Ésta faríase con materiais vexetais, principalmente pólas, xestas e palla ou colmo. Esta opción minimiza os custos, mais apresenta o inconveniente de ter unha durabilidade moito menor cá da caseta.

Os pescantíns cos que tiven a oportunidade de conversar sobre este particular manifestaron dous detalles que cómpre salientar; así, por unha banda considerarase socioeconómicamente máis rico ao dono dun caneiro dotado de caseta e, pola outra, lonxe do que calquera puidese pensar, a construcción dunha pallaza implica tan só unhas poucas horas -apenas tres ou catro para persoas acostumadas e con boa maña- ademáis de facilitar enormemente a procura e obtención dos materiais constructivos necesarios.

Unha vez rematada a súa construcción, os caneiros xa estarán preparados para agardar o outono e a chegada das crecidas, época ideal do ano para poñelos en funcionamento.

\section{REDES, BARCAS E COMPLEMENTOS}

A principal arte de pesca empregada no caneiro recibe o nome de rede de canal ou simplesmente rede. $\mathrm{O}$ aparello (ver Fig. 4a) articúlase por medio dun arco de dimensións variables, mais xeralmente de entre 1'5-2 metros de altura e 1'5 de anchura. $\mathrm{O}$ arco soe estar feito de madeira de loureiro e a el cínguese a rede por medio de varias cordas.

A rede ten feitío rectangular, e o tamaño da súa entrada pódese regular en altura consonte á fondura das augas pois, ao amarrala ao arco, atarase tendo en conta esta variable imposta pola conxuntura do río no momento da pesca. A materia prima da rede era antigamente o cáñamo ou o liño, mais co devir do tempo foise introducindo aos poucos o nylon, que non apodrecía e garantía unha maior durabilidade.

A rede soe ter unha longura de entre catro e seis metros, namentras que o seu ancho míngua progresivamente dos 1' $5 \mathrm{~m}$. da boca até os 0'5 m. do rabo. Non leva cortizas nen pesas de ningunha caste, e tampouco

"CUADERNOS DE ESTUDIOS GALLEGOS", Tomo XLV, Fascículo 110, Santiago 1998. 

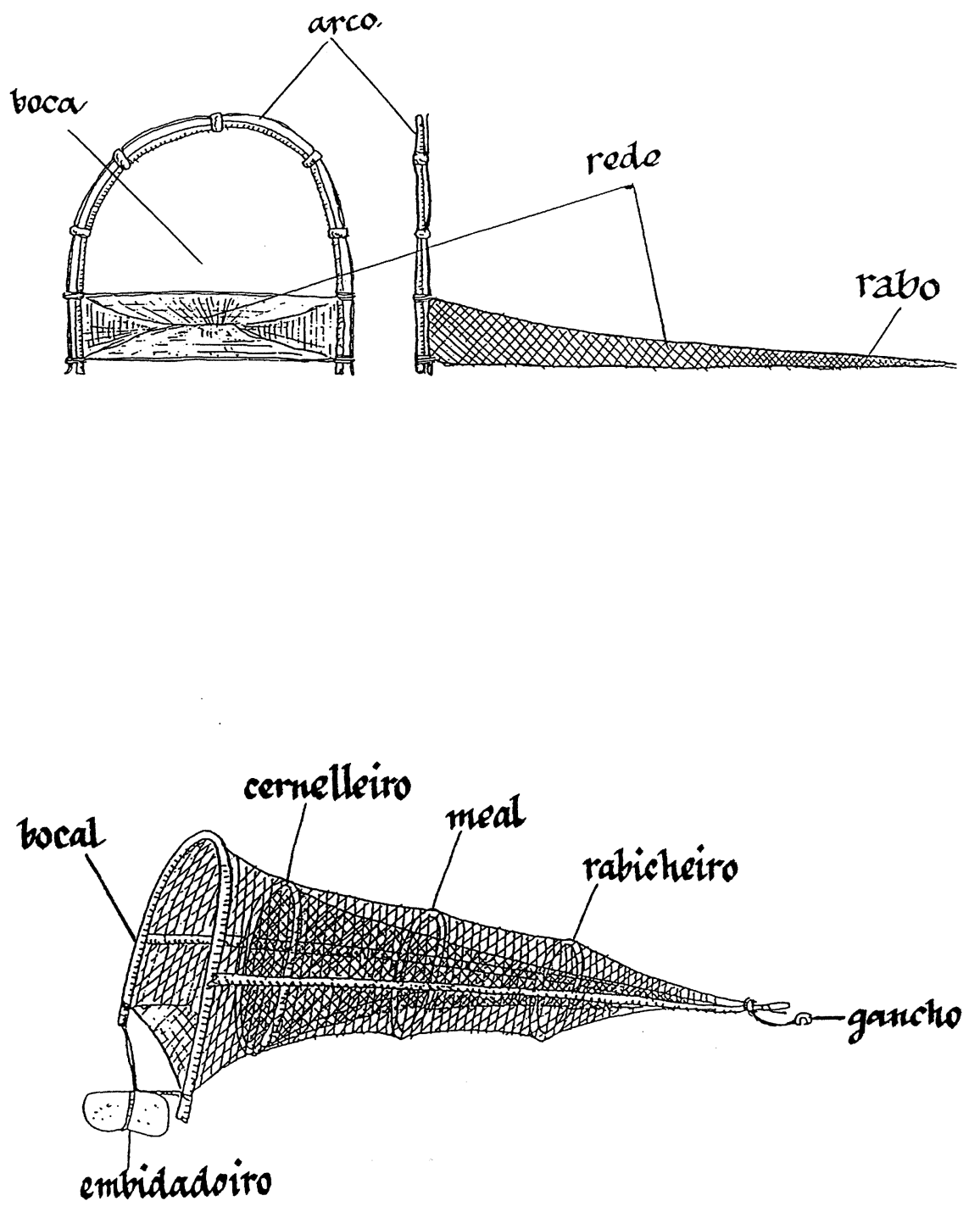

Fig. 4.- a) Rede de caneiro. b) Rede de pesqueira ou Biturón. 

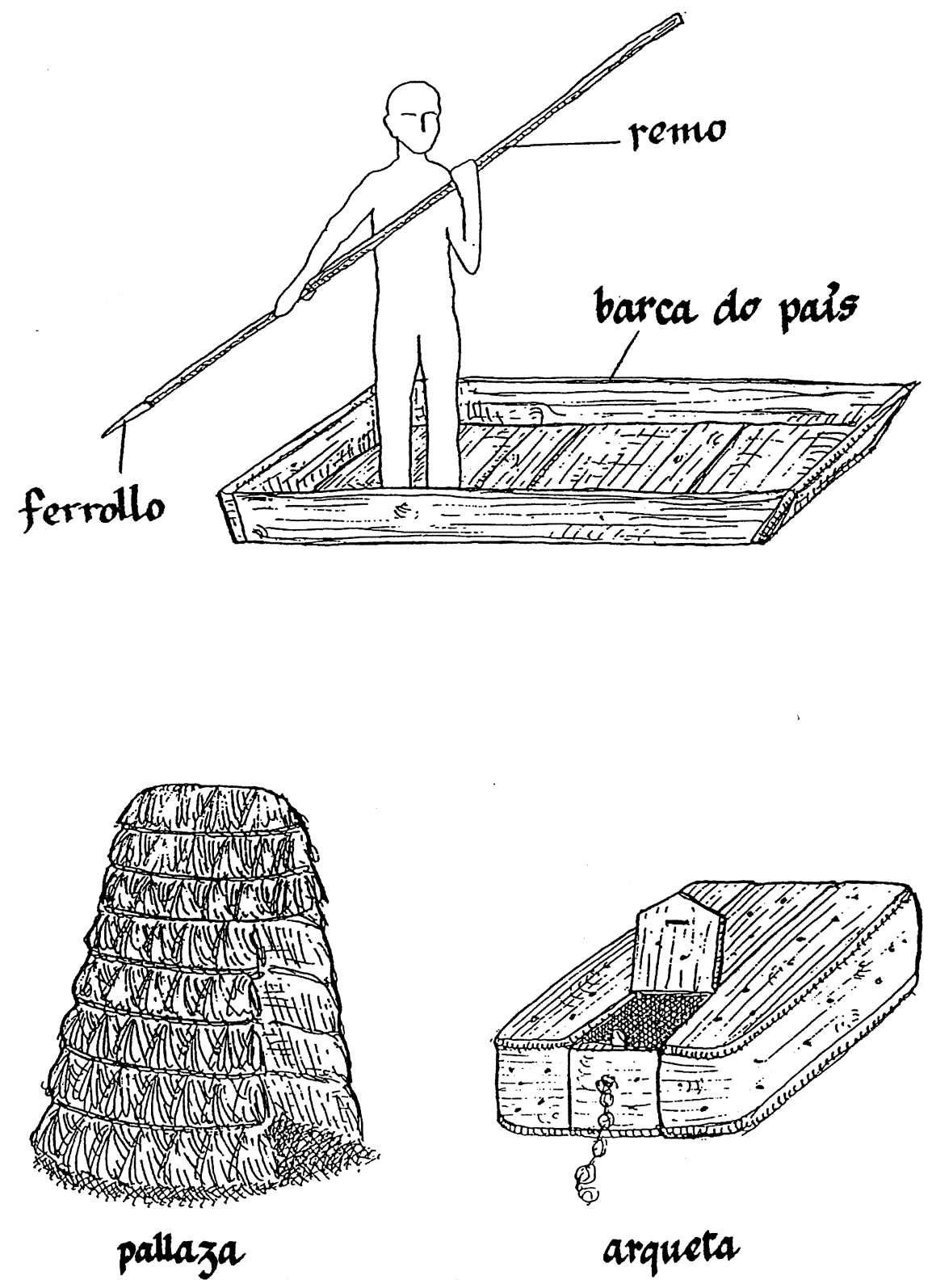

\section{arqueta}

Fig. 5.- a) Barca do país. b) Pallaza. c) Arqueta. 
era cebada con reclamo algún. A súa malla estréitase desde os $5 \times 5 \mathrm{cms}$. da boca até $\mathrm{o} 1 \mathrm{x} 1 \mathrm{~cm}$. do rabo. Na elaboración e mantimento das redes traballan homes e mulleres coas clásicas agullas de madeira antes de chegar a época das crecidas.

Cómpre salientar o peculiar feitío deste aparello, se ben pódese documentar un paralelo morfolóxico inmediato no biturón xigante empregado polos furtivos do tramo inferior do Miño e que éstes armaban nas pesqueiras cando andaban á procura da lamprea (ver Fig. 4b).

Outro elemento da cultura material de especial interese para nós constitúeno as barcas do país (ver Fig. 5a) nas que os pescantíns se dirixían desde terra aos caneiros. Decidín incluír esta embarcación no presente apartado de complementos do caneiro, se ben debe ficar perfectamente claro que a barca era usada polas xentes de Portomarín para outros moitos cometidos que nada teñen que ver co que aquí estamos a falar. Éstas son de proa biselada en cuña, popa achatada e fundo achairado, carecendo de quilla algunha. Para se desprazaren, os homes facían forza co remo, no extremo do cal hai unha ponta de ferro chamada ferrón ou ferrollo e que cravaban no fundo do río para avanzaren con el a xeito de pértega.

Non podemos tampouco esquencer aquí as pallazas ou pallozas (ver Fig. 5b) ergueitas temporalmente para acobillar durante as noitadas de pesca aos pescantíns. Feitas de pólas, palla e xestas, manteñen a calor no interior e protexen do frío e das inclemencias de fóra.

Finalmente, un aparello curioso e enormemente funcional era tamén usado polos pescadores portomarinenses; trátase da arqueta (ver Fig. 5c) ou caixón de madeira no cal se deixaban as anguías que se querían gardar con vida para así mellor conservalas até o momento preciso de retiralas para consumilas.

Estas arquetas ficaban amarradas por unha cadea de ferro á pía e mergullábanse por baixo das augas até se encheren. Era desta maneira que as pezas non inmediatamente consomidas ou comercializadas -agás as destinadas á salgazón- se conservaban dun xeito práctico e permanente.

Un detalle importante é o feito de que Portomarín e os seus habitantes sentían grande fachenda do espectacular tamaño de algunhas das súas capturas. Non era estrano en absoluto que, con intención de sorprender a forasteiros ou a persoas de certa importancia que fixeran fonda na vila, os pescantíns gardaran nas arquetas -entre exemplares máis comúns-aquelas 
anguías de maior peso ou dimensións. Desta peculiaridade me teñen falado diversos pescantíns que aínda lembran a fonda admiración causada por especimes anormalmente grandes na faciana de ilustres personaxes que por alí pasaron algunha vez.

Se ben os complementos dos caneiros son moitos máis dos aquí reseñados, coido que con esta pequena mostra fican expostos os principais. Entre os secundarios poderíamos falar das agullas de madeira para reparar as redes, dos sacos empregados para gardar e transportar as capturas, etc.

\section{A PRÁCTICA DA PESCA E AS NOITADAS}

Logo dos labores de reparación e mantimento dos caneiros e das redes levados a cabo durante o verán, ao chegar os meses de setembro e outubro fan a súa aparición en escea as primeiras choivas. Con elas medra o nível das augas e chegan as riadas. É o momento máis axeitado para a pesca da anguía nos ríos, aínda que ésta se pode demorar en función das choivas -dependendo dos anos-incluso até o Nadal.

Os pescantíns deciden armar o caneiro e acoden a el nas barcas do país a última hora da tarde, xa no solpor. Segundo os nosos informantes, normalmente participan un mínimo de dúas persoas e até un máximo de cinco. Neste labor toman parte homes, mulleres e nenos, se ben o máis frecuente é que sexan os homes os que desenvolvan as tarefas principais por mor da grande forza física que se precisa para desarmar as redes. Nembargantes, tamén temos coñecemento de que as mulleres axudaban na faena e os miúdos ofertaban apoio para tarefas secundarias como alumear ao pescantín cando éste debía retirar a rede.

Tendo en conta o comportamento biolóxico da anguía, ésta, logo de permanecer durante longa parte do ano soterrada nas pozas do río, ao chegar as riadas de setembro e outubro descía ao mar, deixándose levar pola corrente (PARDO Y PUZO, 1911; RODRÍGUEZ et alii, 1983; VILLOCH, 1991). A súa actividade vital desenvólvese normalmente pola noite, momento no cal aproveitan os pescantíns para proceder á súa captura.

As noitadas ou noites de faena consistían no seguinte: o grupo de pescantíns arranxaba os preparativos precisos e logo carregaba o material

"CUADERNOS DE ESTUdios GALLEGOS", Tomo XLV, Fascículo 110, Santiago 1998. 
na barca do país até o caneiro. Unha vez alí, a barca amarrábase cunha corda á parte traseira da pía e comezaba a armarse o caneiro ao tempo que se construía a pallaza cando non contaban con caseta de pedra.

Logo de ter armado o caneiro, os pescantíns garnecíanse no interior da pallaza ou da caseta, segundo o caso, e aproveitaban para cear e falar das súas cousas. Co fin de amenizar a noitada e combater a fresca, acendían unha fogueira para se quecer co lume, e facían café, ben acompañado de augardente, logo de regar a cea con bon viño do país.

Cada pouco tempo algún deles saía fóra e tanteaba as redes para comprobar a marcha da pesca. Cando éstas estaban cheas, todos participaban no seu desarme e inmediato vaciado co fin de aproveitar ben o tempo. A operación repetíase en diversas ocasións, e moitas veces tiñan que baleirar as redes sin que éstas estivesen aínda cheas de peixe por mor da grande cantidade de follas e pólas que nelas entraban arrastradas polo río.

Normalmente procuraban mergullar a parte alta da rede un pouco por baixo da superficie da auga para evitar as cheas de follarasca, mais aínda así esta solución non sempre tiña un resultado satisfactorio. Así decorría a noite. As primeiras anguías cociñábanse en olas de barro ou tixolas de ferro con aceite e graxa de porco, aproveitando deste xeito para terminar de cear e degostar in situ a súa calidade. Normalmente servían de acompañamento ás anguías unhas patacas cocidas ou cachelos.

Nestas noitadas eran frecuentes as queimadas, as longas conversas e un ambiente eminentemente lúdico. Máis dun apañaba algunha que outra bebedeira e remataba lixeiramente contento. As capturas deitábanse en sacos, caixóns de madeira ou arquetas, segundo o fin ao que fosen destinadas.

Cando as capturas eran abondosas dicíase que «as anguías andaban», e cando resultaba todo o contrario, era que simplesmente «non andaban». Os maiores da vila cóntannos que as mellores noites eran as escuras e calmas, é dicir, aquelas nas que non había luar nen vento travesía ou vento do oeste, pois as anguías non gostan da claridade nen do aire de poñente.

Por outra banda, cando as augas baixaban turbulentas ou «lodaba $o$ río» producíanse as maiores capturas. Segundo algún que outro autor, os máis vellos falaban incluso dun volume total de pesca nunha soa riada á volta dos 3.000 quilogramos nos mellores anos (VILLARABID, 1984), aínda que eu non puiden constatar tan abondosas capturas por moito que 
preguntei. Á mañanciña recollíanse as artes, é dicir, desarmábase o caneiro e os pescantíns voltaban a terra cargados de anguías.

Alén do autoconsumo, a pesca tiña unha finalidade esencialmente comercial. É por iso que a grande maioría eran vendidas aínda frescas nas freguesías dos arredores, e tamén salgadas e transportadas cara o resto de Galicia e parte de España. Un remanente de exemplares vivos permanecía nas arquetas amarradas ás pías, moitas das cales constituían os mellores exemplares.

\section{PROPIEDADE, TOPONIMIA, GASTRONOMÍA E FOLCLORE}

A propiedade dos caneiros era familiar e transmisible por herdanza. Non todas as casas posuían caneiros, mais eran libres de construilos se así o desexaban e podían sufragar os dispendios económicos derivados do seu erguemento. Aínda que eran moi poucos os casos, algunhas casas tiñan ata dous caneiros, falándose entón a miúdo dun caneiro vello e dun caneiro novo.

Normalmente son as propias familias posuidoras as que explotan os caneiros, aínda que poden alugar o seu uso en troques dunha porcentaxe sobre a cantidade total das capturas. Até o ano 1932 existiron aforamentos, algúns deles incluso recollidos no cadastro de Ensenada, mais unha lei do mentado ano aboliunos.

Non faltan os casos nos que algúns propietarios deixaban incluso armar os caneiros a outros veciños sen pedir nada a cambio, ou incluso compartían a mesma faena membros da familia posuidora e veciños alleos ao caneiro en cuestión, ben como amostra de axuda desinteresada, ben para repartir beneficios.

A explotación do caneiro era básicamente familiar, aínda que o seu titular legal era únicamente o primoxénito ou a primoxénita; é por iso frecuente ouvir falar de caneiros concretos co nome do seu casal ou do propietario, coma por exemplo o Caneiro de Arenas, o de Ribeira, o de Patrón, o de Vila, o de Merelle, etc., todos eles referentes ao nome co que era popularmente coñecida a familia ou o titular que detentaba a súa explotación.

A presencia de caneiros, como xa vimos, recóllese en diversos topónimos ao longo e ancho de Galicia, especialmente na microtoponimia

"CUADERNOS DE ESTUDIOS GALLEGOS", Tomo XLV, Fascículo 110, Santiago 1998. 
de aldeas, lugares e afluentes. No caso concreto da vila de Portomarín, aínda hoxe existe un nome de lugar chamado Caneiros, e nas inmediacións da aldea de Suar documéntase unha vía de paso que atravesa o Río Loio coñecida como Portocaneiro. Non faltan pois, testemuñas toponímicas da importancia que acadaron estas construccións nas terras mentadas.

Sexa como fora, o legado cultural dos caneiros non remata aquí. No aspecto gastronómico, as anguías de Portomarín teñen sona coma un dos productos máis exquisitos da mesa galega, sendo a súa preparación máis frecuente a xeito de fritura ou guisado. Por outra banda, ninguén pode esquencer os dous embaixadores máis representativos da gastronomía portomarinense: a empanada de anguías e a augardente.

$\mathrm{Na}$ dieta tradicional da vila a anguía xogaba un papel primordial, especialmente a cotío á hora do almorzo e na Pascua, cando na grande festa caseira que acostumaba celebrarse por entón os familiares e amigos reuníanse nas casas e degostaban a empanada de anguías ao tempo que daban boa conta de abondante carne de porco.

Incluso a nível popular consérvanse nesta vila ditados, refráns e expresións que fan referencia ao mundo dos caneiros e das anguías. Así, é frecuente ouvir dicir que alguén «escapa como a anguía», ou que " $a$ anguía na empanada faiche boa merendada», tal e como me contaron diversos informantes.

Sen ir máis lonxe, etnógrafos de prestixio recoñecido coma Ferro teñen recollido o ditado «A anguía, en empanada, e a lamprea, escabechada» (FERRO, 1987: 96) ou «Cando ruxen os cachós de Costa é que vai chover», que quere dicir que cando fai moito barullo a auga que cae do caneiro de Costa achéganse as choivas (PAZ, 1961: 156). Ademáis, todo o mundo coñece a expresión «a río revolto, todo son beneficios», $\mathrm{e}$ algúns filólogos recolleron en terras de Paradela o ditado «cando a lavan os caneiros non can as anguías», que fai referencia ao feito de que as cheas, cando desbordan os guiares do caneiro, impeden que caian neste as anguías porque a auga pasa por riba das espigas e favorece a fuxida do peixe (PALLARES, 1990: 131). 


\section{SOBRE A POSIBLE ORIXE DOS CANEIROS}

Como resulta lóxico pensar, os caneiros non son as únicas construccións populares artelladas para a pesca fluvial en Galicia. Entre outras moitas destas construccións, destacarei aquí especialmente os chamados pescos ou pesqueiras, especialmente os do Baixo Miño, nos que teñen reparado diversos autores (LORENZO, 1982; ALONSO, 1980; LLANO, 1981; PORTELA et alii, 1981; BAS, 1983; PORTELA, 1985; ALONSO, 1989; etc.). Outro paralelo edilicio -se cadra máis interesante a nível morfolóxico, mais non funcional- o constitúen os chamados foxos, empregados para a captura de raposos e lobos. O interesante deste tipo de construccións é a sinxeleza e o primitivismo do seu deseño.

No tocante á orixe dos caneiros, ésta pérdese na brétema dos tempos, aínda que se cadra os socorridos exemplos de pesqueiras e foxos poden axudarnos neste sentido. Así, no caso das pesqueiras, éstas aparecen citadas documentalmente por vez primeira durante o século IX baixo o nome de piscarias (CABEZA, 1992). Os foxos rexístranse pola súa banda alomenos xa dende o século X e coa denominación de fogios (LLANO, 1981).

O certo é que os habitantes máis vellos de Portomarín cos que falei e hoxendía moitos deles xa xubilados, lémbranse dos caneiros «de toda a vida» e cando menos dende o tempo dos seus abós e bisabós, co cal temos a seguranza mínima de poder remontalos por testemuñas orais até mediados do século XIX.

Documentalmente só teño constancia da súa existencia xa no século XVIII gracias aos datos recollidos no interrogatorio do cadastro de Ensenada, pero é posible que teñamos referencias escritas da súa existencia en Galicia xa probablemente nos séculos XI e XII.

Para confirmar esta hipótese habería que proceder a unha pormenorizada e detida análise da documentación conservada -publicada ou nonna procura de referentes válidos que desboten ou reafirmen a mentada posibilidade.

Nembargantes, sobre a xénese en Galicia deste tipo de construccións aínda se pode dicir moito máis se temos en conta certos indicadores da súa presumible antigüidade. Imos agora procurar percorrer estes indicios para así poder xustificar a nosa hipótese sobre a recuada orixe nos tempos, cando menos medievais, dos caneiros.

"CUADERNOS DE ESTUDIOS GALLEGOS", Tomo XLV, Fascículo 110, Santiago 1998. 

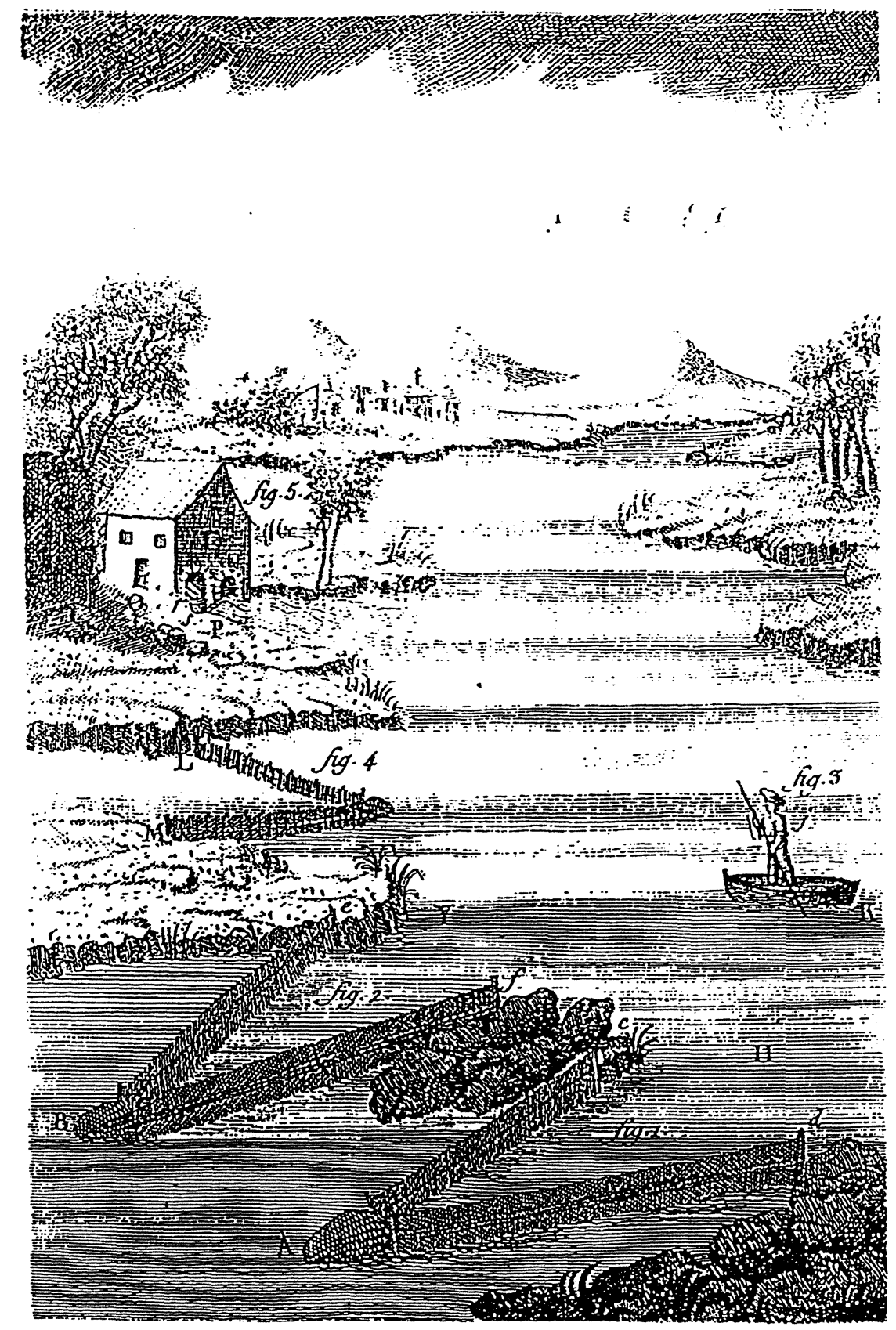

Fig. 6.- Gravado do século XVIII amosando un «cañal» da época. 
A finais do século XVIII, o comisario real de guerra da Marina española D. Antonio Sáñez Reguart elaborou un Diccionario histórico de las artes de pesca nacional. Nel podemos constatar que os cañales facíanse por aquel entón con canas (ver Fig. 6) e que abondaban por terras peninsulares (SÁÑEZ REGUART, 1791-95)

No mesmo século XVIII, mais cara ao ano de 1753, o cadastro de Ensenada recollía no seu interrogatorio xeral diversas informacións referentes ás freguesías de San Nicolás ou San Xoán e San Pedro de Portomarín. Ao tratar da cuestión número dezasete obtemos que a freguesía de San Xoán posuía dez caneiros pertencentes a outros tantos particulares, e a de San Pedro tres, dos cales un era posuído por un particular, outro era arrendado en especie polo Cabido compostelán e outro era igualmente explotado polo Marqués de Bóveda.

Polo de agora resulta irrefutable o feito de que no Miño temos caneiros documentados, cando menos, a mediados do século XVIII. Se analisamos os textos do etnógrafo lusitano José Leite de Vasconcellos tiramos a conclusión de que este procedemento específico de pesca fluvial era xa empregado en Portugal no século XIII segundo as Inquisitiones (VASCONCELLOS, 1958, Vol. V: 368-369).

E até aquí documéntase, polo de agora, o texto máis antigo que faga unha clara relación aos caneiros. Fica exposta pois a nosa hipótese sobre a súa máis antiga constatación documental. Non sería de estranar que, revisando outros documentos de épocas máis recuadas, poidésemos retraer sensiblemente a súa cronoloxía de aparición.

\section{VALORACIÓN FINAL E PERSPECTIVAS DE FUTURO}

Como xa temos visto ao longo deste traballo, os caneiros representan un determinado sistema de vida e de explotación económica do medio fluvial vencellado a tempos pasados. Nestas construccións recóllese a sabiduría popular transmitida de xeración en xeración dende tempos inmemoriais, cun profundo coñecemento das técnicas construtivas, do emprego de materiais axeitados, do aproveitamento racional da riqueza piscícola, etc.

A perfecta e harmónica integración destas estructuras arquitectónicas na paisaxe natural e cultural da vila de Portomarín fican fóra de toda

"CUADERNOS DE ESTUDIOS GALLEGOS", Tomo XLV, Fascículo 110, Santiago 1998. 
dúbida; a súa unicidade plástica como amosa singular da enxeñería popular e a súa funcionalidade manifesta ao longo de moitas centurias constitúen unha clara xustificación do seu vạlor económico e cultural.

Hoxe o futuro dos caneiros de Portomarín está ameazado por múltiples factores, entre os cales destacarían principalmente o seu abandono e os periódicos asulagamentos aos que se ven sometidos coa medra do caudal. Alén disto, o sorprendente descoñecemento da súa existencia pola comunidade científica impediu que fosen estudiados sistemáticamente, sendo este traballo a primeira monografía que se lles adica. Consecuentemente, se non son coñecidos e recoñecidos, difícilmente podemos encetar medidas de protección que garantan a súa conservación, estudo científico e divulgación entre o público xeral.

Imponse unha urxente catalogación, estudo global e recuperación do seu valor patrimonial se non queremos evitar a súa perda definitiva. $\mathrm{O}$ traballo até agora desenvolvido coas pesqueiras do Baixo Miño podería servir perfectamente como referente e exemplo a ter en conta para futuras actuacións. Polo de pronto, o seu inventariado e declaración de Ben de Interese Cultural (B.I.C.) serían de grande utilidade para lles garantir, cando menos, un estatuto patrimonial lexislado e merecente de protección a todos os niveis.

Na memoria dos vellos aínda perdura a lembranza de tempos doutrora nos que os caneiros formaban parte inexcusable da paisaxe económica da vila de Portomarín. As novas xeracións apenas chegan a dexergar a súa primixenia utilidade, e moitos mozos viven de costas a eles. Non deixemos que a desmemoria e o involuntario cultivo do esquecemento nos prive desta singular amosa de enxeñería popular froito da experiencia centenaria e das dotes edilicias dos nosos devanceiros.

A Coruña, xullo de 1997. 


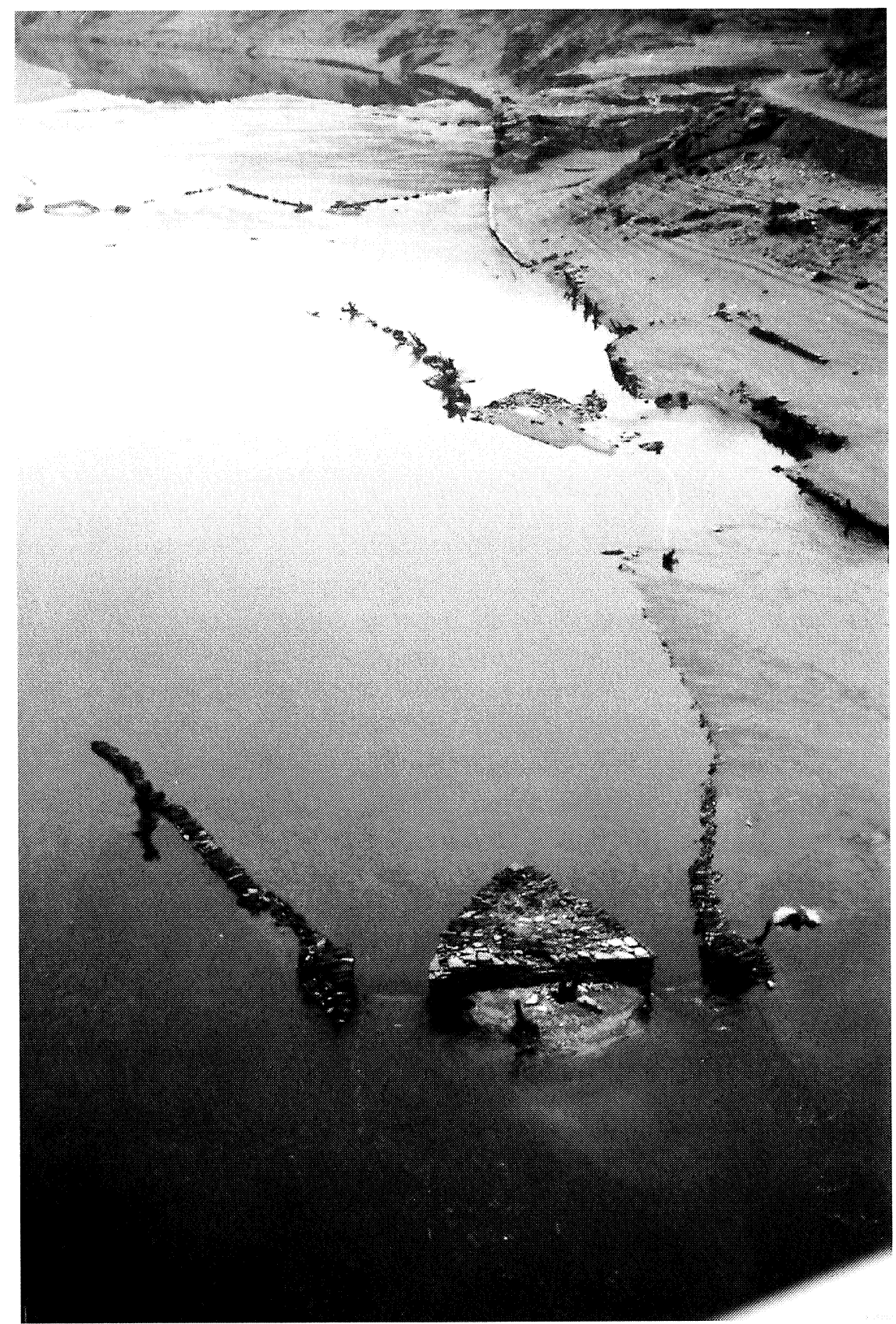

Lám. 1.- Restos de caneiros sobre o Miño en Portomarín. 


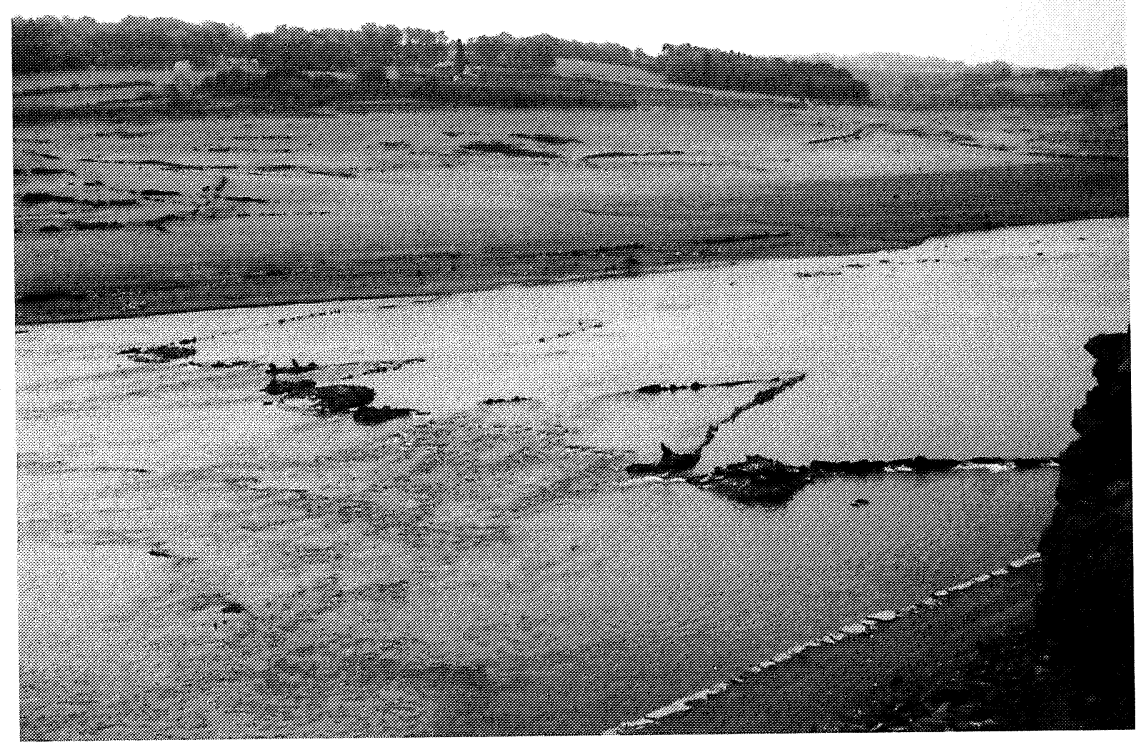

Lám. 2.- Disposición «en batería» para unha mellor pesca.

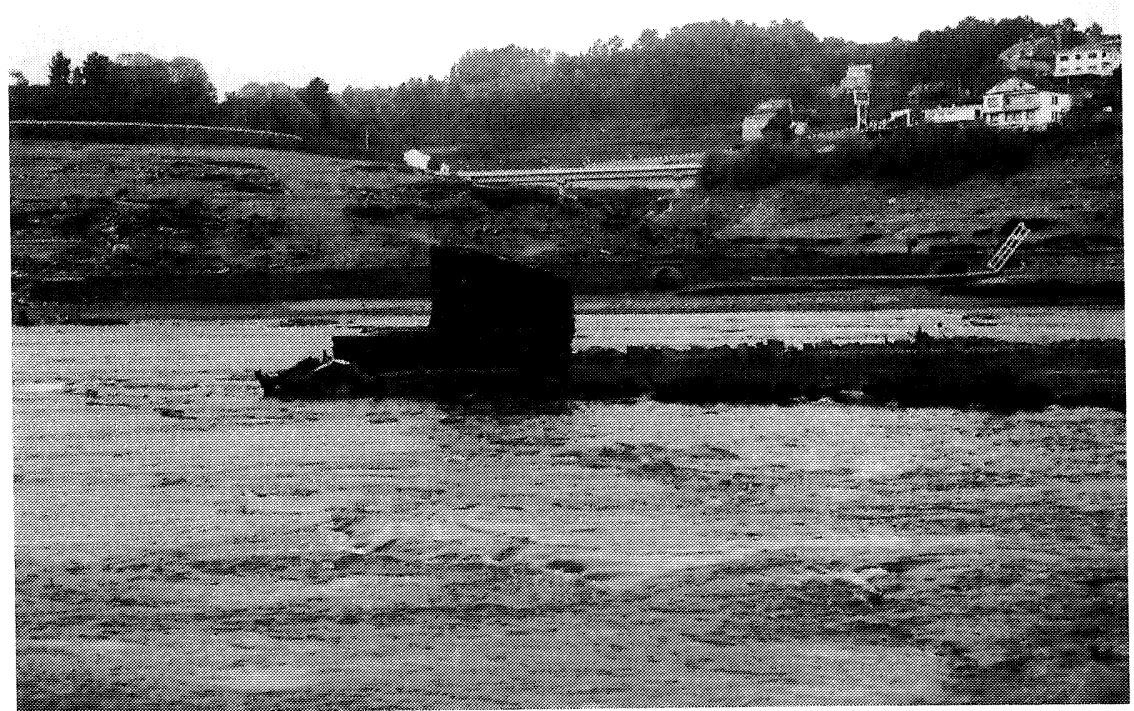

Lám. 3.- Caneiro portomarinense con caseta. 


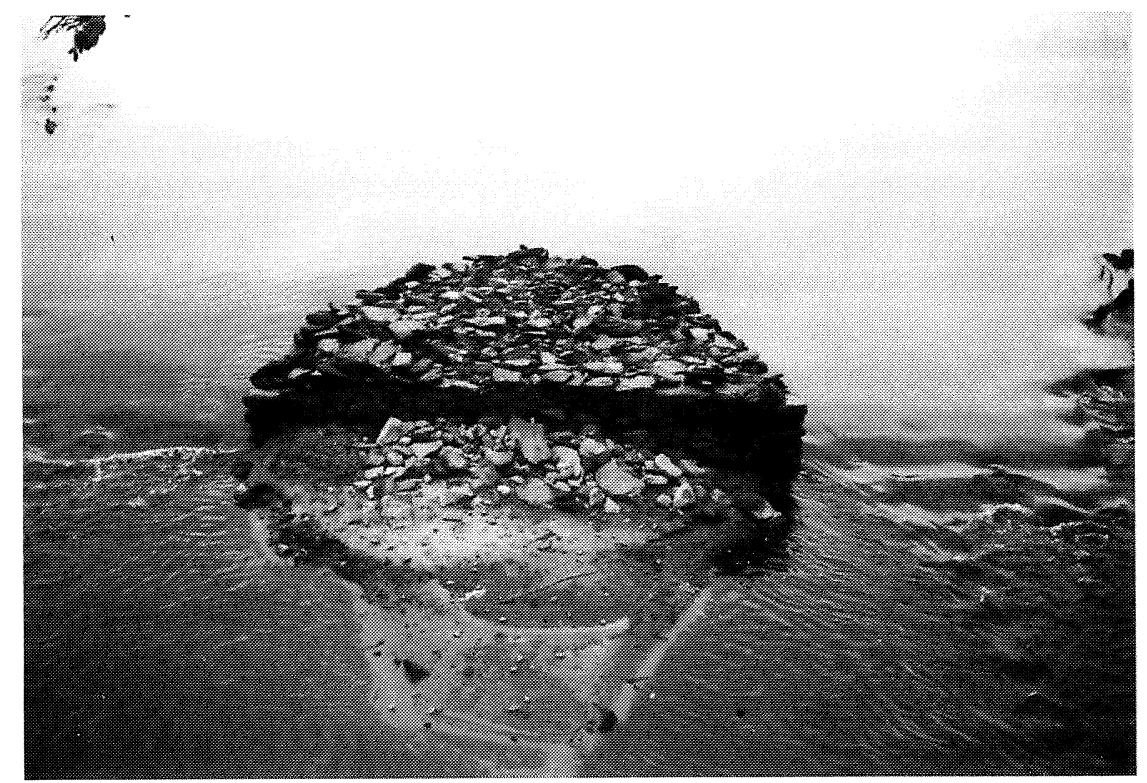

Lám. 4.- Restos dunha pía (Portomarín).

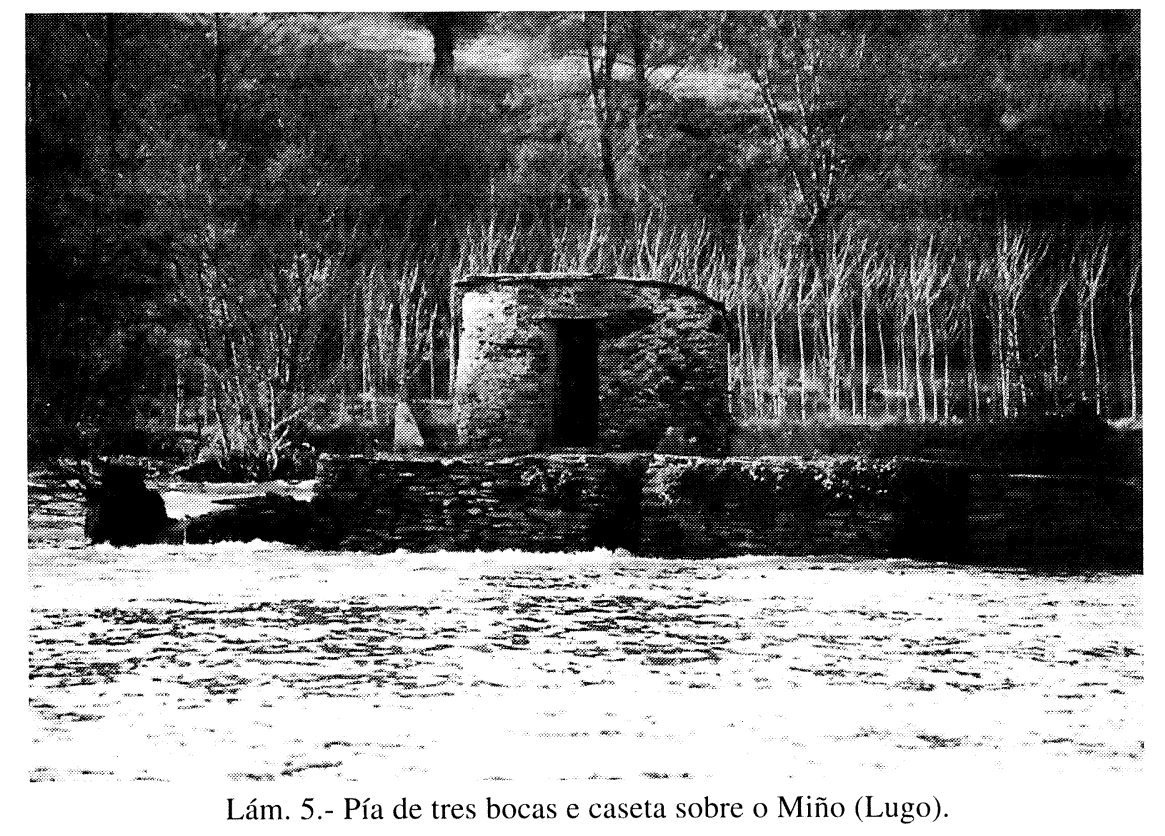




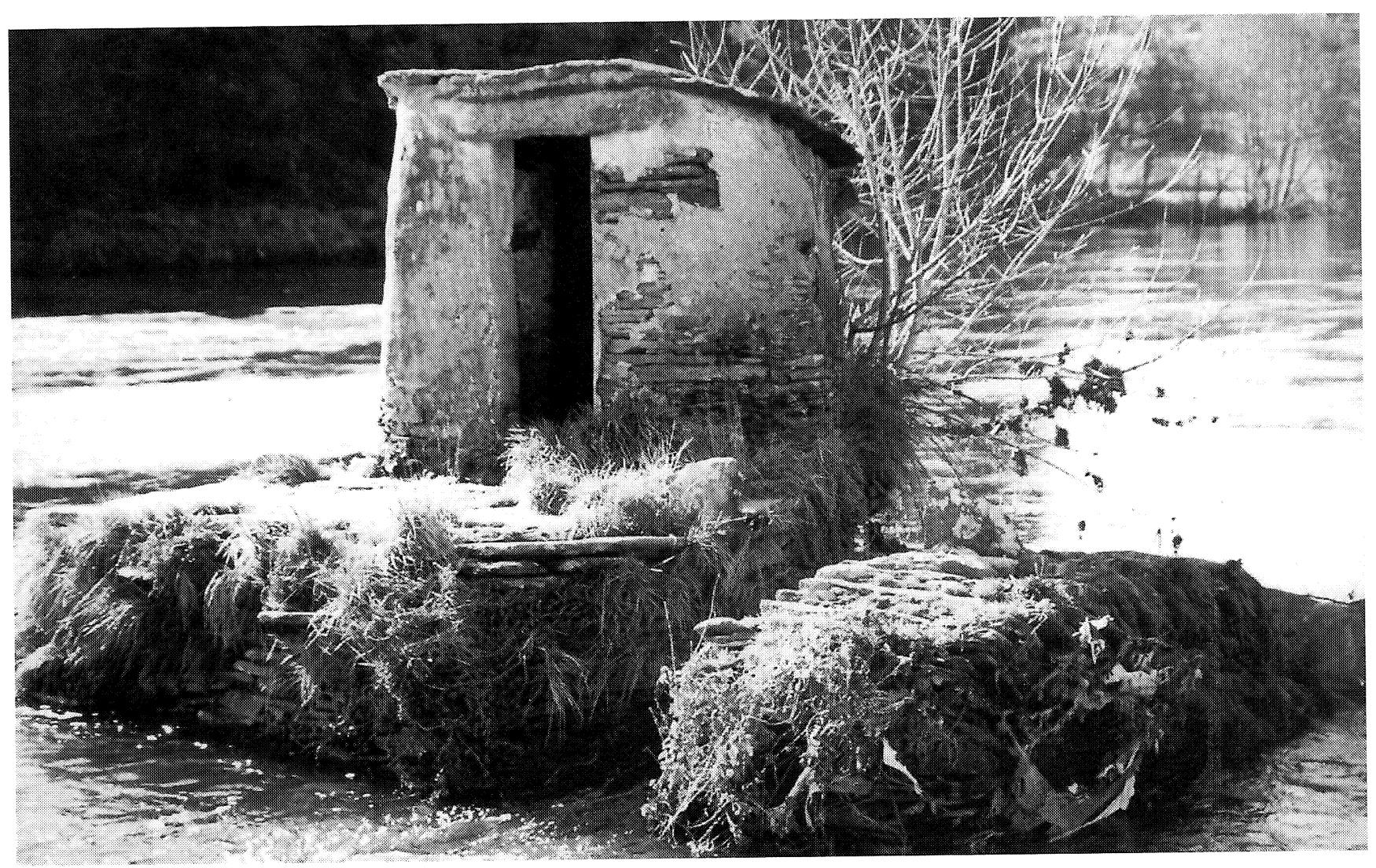

Lám. 6.- Caseta, pía, boca e parte proximal dun espigón (Lugo). 


\section{BIBLIOGRAFÍA}

ALONSO, E. (1980): Bajo Miño y Costa Sur. Imp. J. A. Vicente, Vigo [2 $\left.2^{\mathrm{a}} \mathrm{Ed}.\right]$.

ALONSO, E. (1989): Pescadores del Río Miño (tramo gallego-portugués). Publicacións da Deputación de Pontevedra, Vigo.

BAS LÓPEZ, B. (1983): As construcións populares: un tema de etnografía en Galicia. Cuadernos do Seminario de Sargadelos, vol. 44. Ediciós do Castro, Sada.

CABEZA, F. (1992): Os nomes de lugar. Topónimos de Galicia: a súa orixe e o seu significado. Xerais, Vigo.

ENCICLOPEDIA UNIVERSAL ILUSTRADA ESPASA-CALPE (1958) v. «cañal» (vol. XI, p. 308). Espasa-Calpe, Madrid.

FERRO RUIBAL, X. (1987): Refraneiro galego básico. Galaxia, Vigo.

LABRADA, J. L. (1804): Descripción económica del Reyno de Galicia. Reed. Galaxia, Vigo.

LADRA, X. L. (1997): Os caneiros do Miño: Estudio etnográfico dun tradicional sistema de pesca fluvial en perigo de desaparición. Traballo inédito.

LORENZO FERNÁNDEZ, X. (1982): O mar e os ríos. Galaxia, Vigo.

LLANO CABADO, P. de (1981): Arquitectura popular en Galicia. C.O.A.G., Vigo.

MOLINA, B. S. de (1550): Descripción del Reyno de Galizia. Reed. de Bibliófilos Gallegos, Compostela, 1949.

PALLARES LÓPEZ, M. R. (1990): Vocabulario do Concello de Paradela (Lugo). Publicacións da Deputación de Lugo, Lugo.

"CUADERNOS DE ESTUDIOS GALLEGOS", Tomo XLV, Fascículo 110, Santiago 1998. 
PARDO Y PUZO, A. (1911): Anguilas y angulas. Librería de Francisco Beltrán, Madrid.

PAZ LÓPEZ, G. (1961): Portomarín. Monografía geográfica de una villa medieval. C.S.I.C.

PEDRET CASADO, P. (1950): «Un viaje de Cornide por Galicia» [Cuadernos de Estudios Gallegos, vol. V, fascículo n ${ }^{\circ} 15$, páxs. 133-143] C.S.I.C., Compostela.

PORTELA, C. et al. (1981): «Informe sobre as pesqueiras do río Miño» [VV.AA.: Galicia: A destrucción e a integración do Patrimonio Arquitectónico, páxs. 86-95]. Actas das III Xornadas de arquitectura galega. Publicacións do C.O.A.G., Compostela.

PORTELA FERNÁNDEZ-JARDÓN, C. (1985): As pesqueiras do río Miño. Monografías do Patrimonio Monumental Galego, vol. I. Xunta de Galicia, Compostela.

RODRÍGUEZ GONZÁLEZ, E. (1958): Diccionario Enciclopédico Gallego-Castellano v. «caneiro» (vol. I, páx. 465) e v. «guiar» (vol. II, páx. 429). Galaxia, Vigo.

RODRÍGUEZ SOLÓRZANO, M. et al. (1983): Guía dos peixes de Galicia. Galaxia, Vigo.

SAÑEZ REGUART, A. (1791-1795): Diccionario histórico de las artes de pesca nacional. Reedición do Ministerio de Agricultura, Pesca y Comercio, Madrid [1988].

VASCONCELLOS, J. L. de (1958): Etnografía portuguesa.Vol. V, v. «Canais», páxs.368-369. Imprensa Nacional, Lisboa.

VILLARABID, V. L. (1984): Sarria y el Camino Francés por tierras lucenses. Everest, León.

"CUADERNOS DE ESTUdiOS GALLEGOS", Tomo XLV, Fascículo 110, Santiago 1998 
VILlARABID, V. L.(1985): Del viejo al nuevo Portomarín. Everest, León.

VILLOCH, J. (1991): Guía de los peces de las lonjas de Galicia. Casa das Ciencias, A Coruña. 